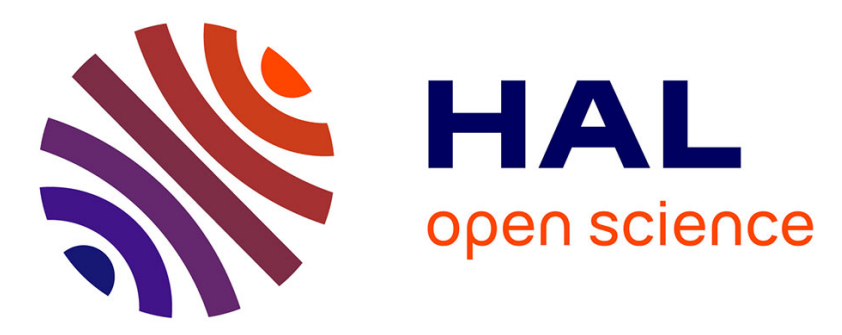

\title{
New fluorescent and electropolymerizable N-azacrown carbazole as a selective probe for iron (III) in aqueous media
}

Pierre-Edouard Danjou, Joel Lyskawa, François Delattre, Matthieu Becuwe, Patrice Woisel, Steven Ruellan, Sophie Fourmentin, Francine Cazier-Dennin

\section{To cite this version:}

Pierre-Edouard Danjou, Joel Lyskawa, François Delattre, Matthieu Becuwe, Patrice Woisel, et al.. New fluorescent and electropolymerizable N-azacrown carbazole as a selective probe for iron (III) in aqueous media. Sensors and Actuators B: Chemical, 2012, 171, pp.1022-1028. 10.1016/j.snb.2012.06.027 . hal-02865832

\section{HAL Id: hal-02865832 \\ https://hal.science/hal-02865832}

Submitted on 21 Jul 2020

HAL is a multi-disciplinary open access archive for the deposit and dissemination of scientific research documents, whether they are published or not. The documents may come from teaching and research institutions in France or abroad, or from public or private research centers.
L'archive ouverte pluridisciplinaire HAL, est destinée au dépôt et à la diffusion de documents scientifiques de niveau recherche, publiés ou non, émanant des établissements d'enseignement et de recherche français ou étrangers, des laboratoires publics ou privés. 


\title{
New fluorescent and electropolymerizable $N$-azacrown carbazole as a selective probe for iron (III) in aqueous media
}

\author{
Pierre-Edouard Danjou ${ }^{\mathrm{a}, \mathrm{b}}$, Joël Lyskawa $^{\mathrm{a}, \mathrm{c}}$, François Delattre ${ }^{\mathrm{a}, \mathrm{b}}$, Matthieu Becuwe ${ }^{\mathrm{a}, \mathrm{b}}$, Patrice Woisel ${ }^{\mathrm{a}, \mathrm{c}}$, \\ Steven Ruellan ${ }^{\mathrm{a}, \mathrm{b}}$, Sophie Fourmentin ${ }^{\mathrm{a}, \mathrm{b}}$, Francine Cazier-Dennin ${ }^{\mathrm{a}, \mathrm{b}, *}$ \\ ${ }^{a}$ Univ. Lille Nord de France, F-5900 Lille, France \\ ${ }^{\mathrm{b}}$ ULCO, UCEIV, F-59140 Dunkerque, France \\ ${ }^{\mathrm{c}}$ USTL ENSCL, UMET, CNRS, UMR 8207, F-59650 Villeneuve d'Ascq, France
}

E-mail address: dennin@univ-littoral.fr (F. Cazier-Dennin).

\begin{abstract}
A b s t r a c t

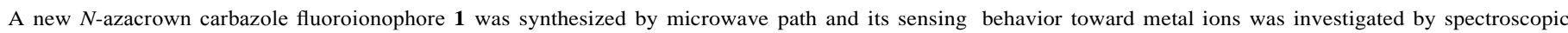

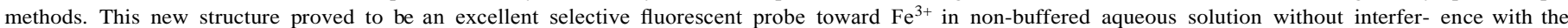

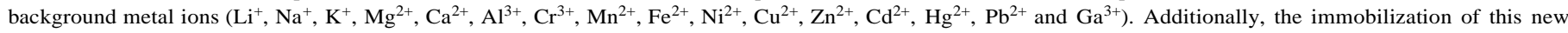
selective iron probe was successfully achieved on gold electrode by electro-polymerization and monitored by EQCM.
\end{abstract}

\section{Introduction}

In the past decade the research of highly selective and sensitive organic fluorescent probes for metal ions recognition has gained extreme importance in environmental and biological area [1-3]. This is due to the fact that, among the numerous analytical methods, the fluorescence one is a great tool owing to its high sensitivity, and relatively simple instrumentation [4,5]. It also allows a real-time, nondestructive detection and/or quantification of chemical species. Besides the development of fluoroionophores for metal ions of groups I and II, significant exploration of fluorescent molecular sen- sors and switches for heavy transition metal (HTM) ions are actually involved [6-8]. Concerning HTM ions detection, fluorimetric anal- ysis of iron [9-17] has nowadays attracted a great deal of attention due to its important role in the fields of environmental monitoring and biological science [18]. It could be noticed that literature gives only few examples of iron chemosensors operating in water and in most cases, these operate in buffered solutions due to the $\mathrm{pH}$ depen- dence of their fluorescence properties [19-22]. Among fluorescent chemosensors, those incorporating a carbazole core appear to be highly promising derivatives due to their attractive fluorescent properties and their ability to be electropolymerized in order to

form a thin film onto metal surfaces [23]. The polymer-coated electrodes then obtained may be used for electrocatalysis, electronics, photoelectronics and photo-electrochemistry. Recently, polycar- bazole derivatives were used to develop copper (II) ion-selective microelectrochemical transistors [24].

Consequently, in our continuing program on the design and synthesis of new chemosensors for recognition of environmen- tal molecular species [25,26] and more particularly HTM [27], we report here an easy and rapid microwave assisted organic synthesis (MAOS) of a new selective iron (III) water soluble fluo- roionophore $\mathbf{1}$. This new iron molecular sensor was designed with typical fluorophore-spacerreceptor format comprising a fluores- cent carbazole moiety linked to an aza-15-crown-5 with or without $N$-carbonyl methylene arm (compounds 1 and 4 respectively, Scheme 1). The photoluminescent properties of the complexation phenomenon of this new fluorescent probe were investigated in the presence of HTM and alkali metal ions. Finally, the redox prop- erties of the carbazole unit were exploited to electropolymerized the aza-15-crown-5 receptor onto a gold surface with an EQCM monitoring.

\section{Experimental}

\subsection{Materials and instrumentations}

Perchlorate salts $\left(\mathrm{Li}^{+}, \mathrm{Na}^{+}, \mathrm{K}^{+}, \mathrm{Mg}^{2+}, \mathrm{Ca}^{2+}, \mathrm{Al}^{3+}, \mathrm{Cr}^{3+}, \mathrm{Mn}^{2+}, \mathrm{Fe}^{2+}, \mathrm{Fe}^{3+}\right.$, $\mathrm{Ni}^{2+}, \mathrm{Cu}^{2+}, \mathrm{Zn}^{2+}, \mathrm{Cd}^{2+}, \mathrm{Hg}^{2+}, \mathrm{Pb}^{2+}, \mathrm{Ga}^{3+}$ ) were used as the

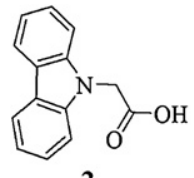

2

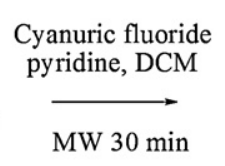

MW $30 \mathrm{~min}$

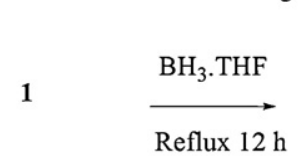

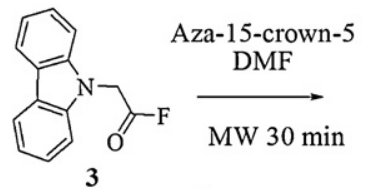

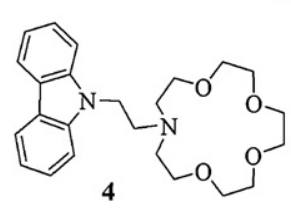

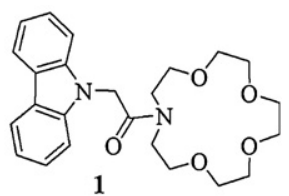

1

Scheme 1. Synthesis of chemosensors 1 and 4. 
metal cations source for fluorescence spectroscopy. Iron chloride salt was used as the metal cation source for infrared spectroscopy. All the chemicals used were purchased from Acros Organic or Sigma Aldrich and were used as received without further purification. Microwave-assisted reactions were performed on a monomode reactor Synthewave Prolabo402 $(300 \mathrm{~W})$ equipped with infrared pyrometer control and stirring mechanically. ${ }^{1} \mathrm{H}$ and ${ }^{13} \mathrm{C}$ NMR spec- tra were recorded with a Bruker Avance $250 \mathrm{MHz}$ spectrometer. Mass spectra were measured using a Platform II Micromass Appa- ratus. IR spectra were recorded using a Perkin-Elmer instrument. Fluorescence spectra were recorded using a Perkin-Elmer LS50B spectrometer. Electrochemical experiments were performed using an Autolab PGSTAT 30 workstation. A three electrode configuration was used with a platinum or gold disk as the working electrode and platinum wire as a counter electrode. An $\mathrm{Ag} / \mathrm{AgCl}$ electrode was used as a reference. EQCM measurements were performed using a Maxtek RQCM apparatus with $5 \mathrm{MHz}$ AT-cut gold crystal (Maxtek P/N 149211-1 Model SC-501-1).

\subsection{Computational methodology}

To obtain more information about the conformational changes of the crown ethers used upon complexation with iron ion, the molecular structures of the free ligands and his 1:1 complex with $\mathrm{Fe}^{3+}$ were carried out using the Spartan software of Wavefunction Inc. The preliminary conformational distribution search has been performed by using the MMFF94 s molecular mechanics force field. The structures were then optimized based on the $6.31 \mathrm{G}^{*}$ basic set at the restricted Hartree-Fock (RHF) level of theory.

\subsection{Synthesis}

\subsubsection{2-(9H-carbazol-9-yl)acetyl fluoride (3)}

To an ice-cold solution of 2-(9H-carbazol-9-yl)acetic acid $2(1.00 \mathrm{~g}$; $4.44 \mathrm{mmol})$ in $\mathrm{CH}_{2} \mathrm{Cl}_{2}$ under nitrogen atmosphere, pyri- dine $(0.69 \mathrm{~g}$; $8.88 \mathrm{mmol})$ and cyanuric fluoride $(1.19 \mathrm{~g} ; 8.88 \mathrm{mmol})$ were successively added. The resulting solution was irradiated in a focused microwave oven at $40{ }^{\circ} \mathrm{C}$ for $30 \mathrm{~min}$ and then washed several times with water, dried over anhydrous $\mathrm{MgSO}_{4}$ and concen- trated in vacuum. Compound 3 was isolated as a brown solid. Yield: $98 \%$. ${ }^{1} \mathrm{H}$ NMR (250 $\left.\mathrm{MHz}, \mathrm{CDCl}_{3}\right): 1(\mathrm{ppm}) 5.22(\mathrm{~s}, 2 \mathrm{H}), 7.27-7.35(\mathrm{~m}$, 4H), $7.52(\mathrm{t}, J=7.50 \mathrm{~Hz}, 2 \mathrm{H}), 8.14(\mathrm{~d}, J=7.75 \mathrm{~Hz}, 2 \mathrm{H})$.

\subsubsection{2-(9H-carbazol-9-yl)-1-(1,4,10,13-tetraoxa-7- azacyclopentadecan-7-yl)ethanone \\ (1)}

To a cold solution of aza- 15 -crown-5 $(0.50 \mathrm{~g} ; 2.28 \mathrm{mmol})$ in DMF (10 $\mathrm{mL})$ was added 2-(9H-carbazol-9-yl)acetyl fluoride $3(0.57 \mathrm{~g}$; $2.51 \mathrm{mmol})$. The resulting solution was irradiated in a focused microwave oven at $40{ }^{\circ} \mathrm{C}$ for $30 \mathrm{~min}$ and then concentrated under reduced pressure to give yellow oil which was purified by column chromatography (EtOAc/MeOH 8:2). Crystallization from EtOAc gave the desired amide as a white solid. Yield: $81 \% .{ }^{1} \mathrm{H}$ NMR (Fig. S1, Supplementary data) (250 MHz, $\left.\mathrm{CD}_{3} \mathrm{CN}\right): 1(\mathrm{ppm}) 3.45-3.78(\mathrm{~m}, 18 \mathrm{H})$, $3.90(\mathrm{t}, J=5.40 \mathrm{~Hz}, 2 \mathrm{H}), 5.31(\mathrm{~s}, 2 \mathrm{H}), 7.22(\mathrm{t}, J=7.00 \mathrm{~Hz}$,

2H), 7.39-7.48 (m, 4H), 8.12 (d, $J=7.75 \mathrm{~Hz}, 2 \mathrm{H})$ (Fig S1). ${ }^{13} \mathrm{C}$ NMR

(62.5 MHz, $\mathrm{CD}_{3} \mathrm{CN}$ ) (Fig. S2, Supplementary data): 1 (ppm) 44.0, 48.9, 49.3, 68.1, 69.2, 69.3, 69.4, 69.7, 70.0, 70.4, 108.79, 118.5, 119.7, 122.2, 125.3, 140.9, 167.28 (Fig. S2). Mass $\left(\mathrm{ES}^{+}\right) \mathrm{m} / \mathrm{z}(\%): 427$ $[\mathrm{M}+1]^{+}(10 \%), 449[\mathrm{M}+23]^{+}(100 \%)$.

\subsubsection{2-(9H-carbazol-9-yl)-1-(1,4,10,13-tetraoxa-7- azacyclopentadecan-7-yl)ethane \\ (4)}

$1(500 \mathrm{mg}, 1.17 \mathrm{mmol})$ was dissolved in anhydrous THF $(50 \mathrm{~mL})$ and then was slowly added to $\mathrm{BH}_{3}-\mathrm{THF}(47 \mathrm{~mL}, 1.0 \mathrm{M}, 46.94 \mathrm{mmol})$ at room temperature. The resulting solution was refluxed for $12 \mathrm{~h}$, and the excess borane was eliminated with methanol. Solvents were removed under vacuum and the residue was hydrolyzed in refluxing $\mathrm{MeOH}-\mathrm{H}_{2} \mathrm{O}$ conc. $\mathrm{HCl}(4: 1: 1) 60 \mathrm{~mL}$ for $2 \mathrm{~h}$. The aque- ous layer was basified with $\mathrm{NaHCO}_{3}$ and then extracted by DCM. The resulting oily product was purified by column chromatogra- phy on silica gel (EtOAc/MeOH 1:1). Compound 4 was isolated as brown oil. Yield: $74 \% .{ }^{1} \mathrm{H} \mathrm{NMR}(250 \mathrm{MHz}$, $\mathrm{CD}_{3} \mathrm{CN}$ ) (Fig. S3, Supple- mentary data): $1(\mathrm{ppm}) 2.72(\mathrm{t}, J=5.81 \mathrm{~Hz}$, $4 \mathrm{H}), 2.92(\mathrm{t}, J=7.00 \mathrm{~Hz}, 2 \mathrm{H}), 3.40-3.50(\mathrm{~m}, 16 \mathrm{H}), 4.42(\mathrm{t}, J=7.00 \mathrm{~Hz}$, $2 \mathrm{H}), 7.21(\mathrm{t}, J=7.00 \mathrm{~Hz}$,

2H), 7.43-7.56(m, 4H), 8.11 (d, J=7.62 Hz, 2H). ${ }^{13} \mathrm{CNMR}(62.5 \mathrm{MHz}$, $\mathrm{CD}_{3} \mathrm{CN}$ ) (Fig. S4, Supplementary data): 1 (ppm) 42.5, 55.1, 55.9, 70.6, 70.7, 70.8, 71.2, 110.1, 119.7, 121.0, 123.4, 126.5, 141.3. Mass $\left(\mathrm{ES}^{+}\right)$ $\mathrm{m} / \mathrm{z}(\%): 435[\mathrm{M}+23]^{+}(100 \%)$.

\section{Results and discussion}

\subsection{Synthesis}

Firstly, aza-15-crown-5 was synthesized according to the procedure of Okahara and coworkers [28] from diethanolamine and triethylene glycol ditosylate [29] and 2-(9H-carbazol-9-yl)acetic acid 2 was produced following the procedure of Zhang and al. [30]. Initially the coupling reaction between aza-15-crown-5 and 2 was performed by the well-known DCC/DMAP approach [31] at room temperature for three days as well as MAOS procedure to give $\mathbf{1}$ in moderate yields (50\% and $65 \%$ respectively). Conse- quently to increase yields, we reacted 2 with an excess of cyanuric fluoride [32] by MAOS path to provide in quasi quantitative yield the more reactive $2-(9 \mathrm{H}$-carbazol-9yl)acetylfluoride 3. The $N$ - acylation of aza-15-crown-5 with the $N$ carbazole acyl fluoride derivative $\mathbf{3}$ was then undertaken under microwave irradiation. As predicted, microwave irradiation provided a faster and more effi- cient synthesis of $\mathbf{1}$ with an improved yield of $81 \%$. Furthermore in order to understand the contribution of spacer in the recogni- tion phenomenon, the carbonyl group of the chemosensor 1 was then reduced in anhydrous THF under soft addition of $\mathrm{BH}_{3}-\mathrm{THF}$ 
Table 1

Photophysical parameters of fluorescent crown derivatives $\mathbf{1}$ and $\mathbf{4}$

\begin{tabular}{lllll}
\hline & $\varepsilon\left(\mathrm{M}^{-1} \mathrm{~cm}^{-1}\right)$ & $\mathrm{h}_{\mathrm{exc}}(\mathrm{nm})$ & $\mathrm{h}_{\mathrm{em}}(\mathrm{nm})$ & $\$_{\mathrm{F}}{ }^{a}$ \\
\hline Compound 1 & $1.5 \times 10^{4}$ & 292 & $330-440$ & 0.31 \\
Compound 4 & $1.2 \times 10^{4}$ & 294 & $330-470$ & 0.20 \\
\hline
\end{tabular}

${ }^{\mathrm{a}}$ Quantum yields were estimated by using anthracene as a standard in ethanol.

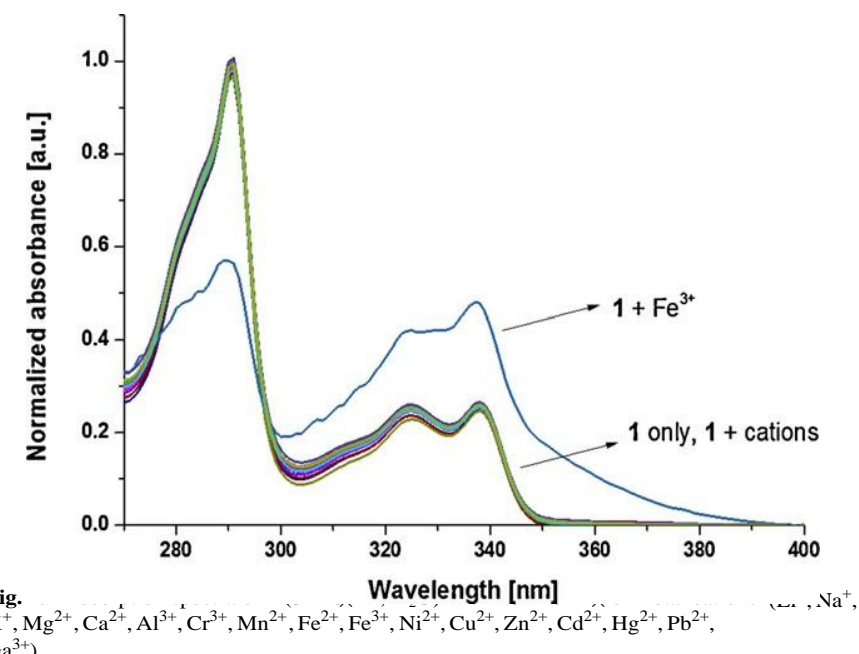

to afford an $\mathrm{N}$-azacrown-carbazole derivative $\mathbf{4}$ without carbonyl entity between fluorophore and crown-ether.

\section{2. $U V-v i s$ absorption and fluorescence properties}

The absorption and emission spectral properties of crown derivatives 1 and 4 were studied in water (Table 1). Absorp- tion spectrum of 1 (Fig. 1) showed absorption bands in range of 270-350 $\mathrm{nm}$ along with a maximum centered at $292 \mathrm{~nm}$ while compound $\mathbf{4}$ have an absorption bands around $275-355 \mathrm{~nm}$ with a maximum absorption slightly shifted at $294 \mathrm{~nm}$ (Fig. S5, Supple- mentary data). As shown in Table 1, the fluorescence quantum yield is higher for the crown derivative 1 than for compound 4.

In order to study the influence of $\mathrm{pH}$ on the spectromet- ric properties, the new fluorescent crown derivatives were first investigated over a $\mathrm{pH}$ range of $2-12$. The results show no sig- nificant change of absorption spectra for compound $\mathbf{1}$ indicating no $\mathrm{pH}$ dependence (Fig. 6A, Supplementary data). Contrary to $\mathbf{1}$, compound $\mathbf{4}$ shows strong $\mathrm{pH}$ dependence (Fig. S6B, Supplemen- tary data). Therefore its $\mathrm{p} K_{\mathrm{a}}$ of 7.8 require to work in buffered

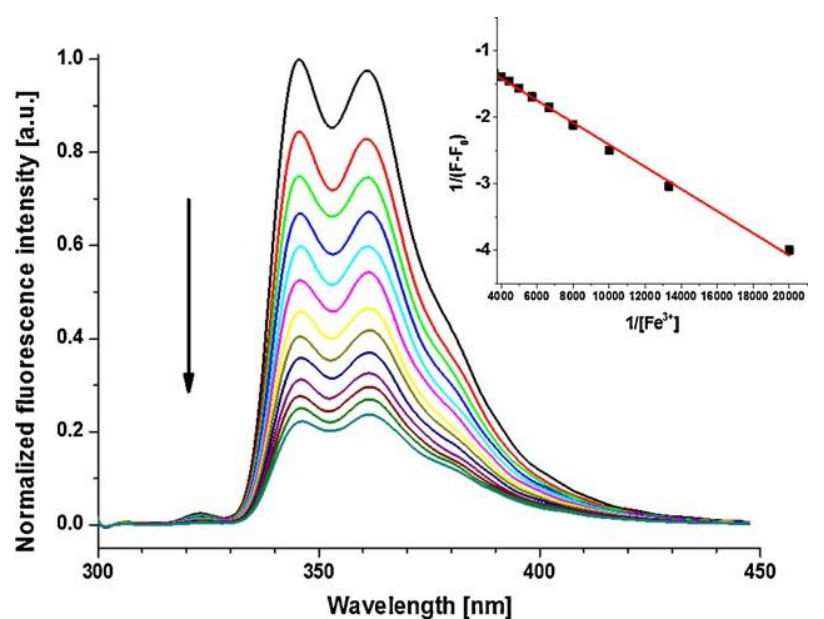

Fig. 3. Fluorescence emission spectrum of $1\left(0,5 \mu \mathrm{M}, \mathrm{h}_{\mathrm{ex}}=292 \mathrm{~nm}\right)$ vs. addition of $\mathrm{Fe}^{3+}$ $(0-300 \mu \mathrm{M})$ in water. Inset: Benesi-Hildebrand plot.

solution at $\mathrm{pH}$ 9. Unfortunately, in these conditions and at this level of concentration, all metals precipitate and it was not possible to carry out UV-vis absorption experiments with compound 4. The absorption spectra of new crown ether 1 were then performed upon addition of various metal ions such as $\mathrm{Li}^{+}, \mathrm{Na}^{+}, \mathrm{K}^{+}, \mathrm{Mg}^{2+}, \mathrm{Ca}^{2+}, \mathrm{Al}^{3+}, \mathrm{Cr}^{3+}, \mathrm{Mn}^{2+}, \mathrm{Fe}^{2+}, \mathrm{Fe}^{3+}, \mathrm{Ni}^{2+}$, $\mathrm{Cu}^{2+}, \mathrm{Zn}^{2+}, \mathrm{Cd}^{2+}, \mathrm{Hg}^{2+}, \mathrm{Pb}^{2+}$ and $\mathrm{Ga}^{3+}$

as perchlorate salts [33]. As shown in Fig. 1, the addition of $\mathrm{Fe}^{3+}$ causes an increase of the absorption band between 330 and $350 \mathrm{~nm}$ while the $\mathrm{G}-\mathrm{G}^{*}$ transition at $292 \mathrm{~nm}$ progressively decrease. In our experiments, the presence of other metal cations doesn't cause any significant alterations of the UV-vis spectra (Fig. 1).

Fig. 2 shows the variation of fluorescence emission after addi- tion of 200 equivalents $(100 \mu \mathrm{M})$ of metal cations to a solution of $\mathbf{1}$ and $\mathbf{4}$ $\left(5.10^{-7} \mathrm{M}\right)$ in aqueous solution at room temperature and with an incubation time of $1 \mathrm{~min}$. As expected from UV absorption of 1 (Fig. 2A), only $\mathrm{Fe}^{3+}$ induced a significant fluorescence quench- ing of up to $39 \%$ suggesting a selectivity phenomenon. To prevent the amine protonation, the fluorescent emission experiments of $\mathbf{4}$ were carried out at $\mathrm{pH}=9$ with addition of the same series of cations (Fig. 2B). The examination of results reveals a decrease of the fluo- rescence intensity for $\mathrm{Fe}^{3+}, \mathrm{Fe}^{2+}$ and $\mathrm{Cu}^{2+}$ species and shows a loss of selectivity toward $\mathrm{Fe}^{3+}$.

In order to calculate the association constants, compounds $\mathbf{1}$ and $\mathbf{4}$ were titrated with $\mathrm{Fe}^{3+}$ and $\mathrm{Fe}^{3+}, \mathrm{Fe}^{2+}$ and $\mathrm{Cu}^{2+}$ perchlorate salts respectively $\left(\mathrm{Fe}^{3+}\right.$ vs. $\mathbf{1}$ as example in Fig. 3). The non-linear regression analysis of fluorescence flattening allowed to estimate the association constant [34] which was compiled in Table 2.
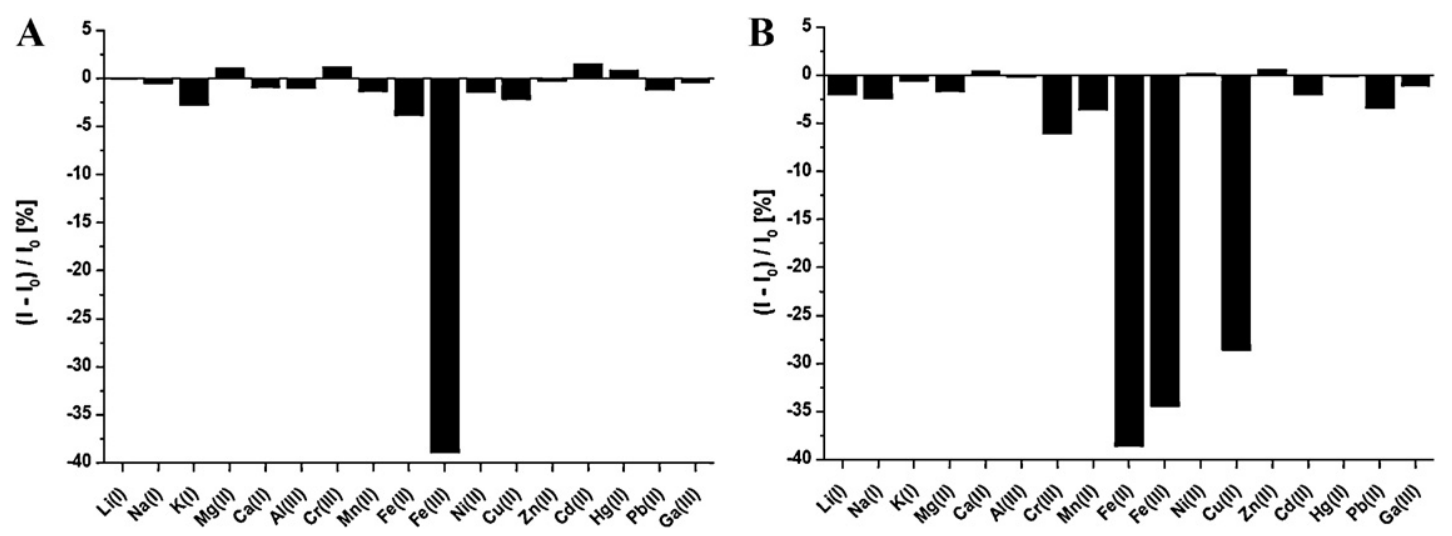

Fig. 2. Change in fluorescence emission of compound 1 (A) and 4 (B) $\left(0.5 \mu \mathrm{M}, \mathrm{h}_{\mathrm{ex}}=292 \mathrm{~nm}\right.$, water) upon addition of 200 equivalents of various metal cations as perchlorate salts. 


\begin{tabular}{|c|c|c|c|}
\hline & $\mathrm{Fe}^{3+}$ & $\mathrm{Fe}^{2+}$ & $\mathrm{Cu}^{2+}$ \\
\hline Compound $\mathbf{1}$ & $7.0 \pm 0.3(2.5 \mu \mathrm{M})$ & - & - \\
\hline Compound 4 & $4.2 \pm 0.15(2.6 \mu \mathrm{M})$ & $4.8 \pm 0.2(2.4 \mu \mathrm{M})$ & $3.7 \pm 0.13(3.1 \mu \mathrm{M})$ \\
\hline
\end{tabular}

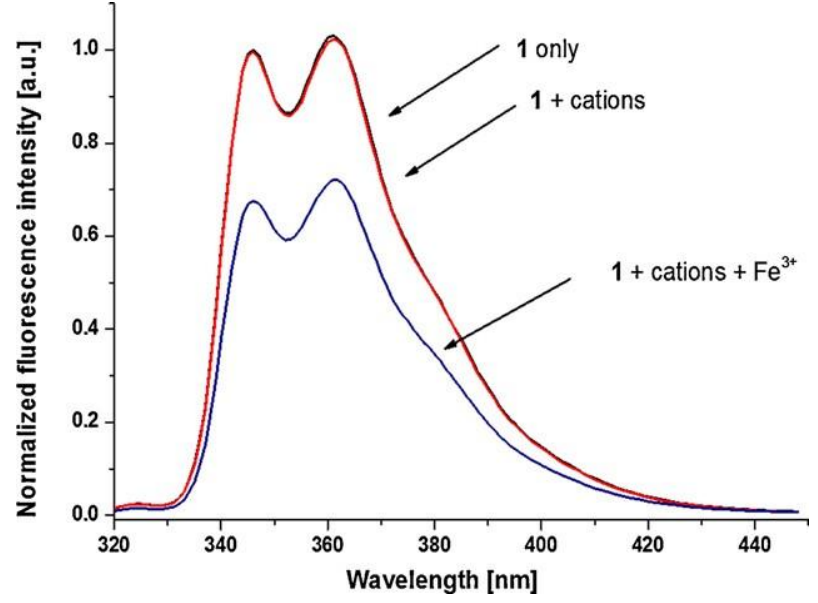

Fig. 4. Fluorescence response of chemosensor $1\left(0,5 \mu \mathrm{M}, \mathrm{h}_{\mathrm{ex}}=292 \mathrm{~nm}\right)$ alone, with 200 equiv. of $\mathrm{Li}^{+}, \mathrm{Na}^{+}, \mathrm{K}^{+}, \mathrm{Mg}^{2+}, \mathrm{Ca}^{2+}, \mathrm{Al}^{3+}, \mathrm{Cr}^{3+}, \mathrm{Mn}^{2+}, \mathrm{Fe}^{2+}, \mathrm{Ni}^{2+}, \mathrm{Zn}^{2+}, \mathrm{Cd}^{2+}, \mathrm{Hg}^{2+}$ $\mathrm{Pb}^{2+}$ and $\mathrm{Ga}^{3+}$ (top) and with addition of 200 equiv. of $\mathrm{Fe}^{3+}$ (bottom).

The association constant of $\mathbf{1}$ vs. $\mathrm{Fe}^{3+}$ is higher compared to the other values obtained for $\mathbf{4}$ and is consistent with a selectiv- ity induced by a specific interaction between the metal ion and the ligand. Furthermore, the calculated limit of detections (LOD) are comparable with dedicated literature $[16,17,35]$.

To confirm the selectivity of fluorescent crown derivative $\mathbf{1}$, we have then performed fluorescence experiment in contaminated medium by various cations. Then, the fluorescence spectrum of $\mathbf{1}$ was recorded in the presence of $\mathrm{Fe}^{3+}$ and an equal amount of each previously mentioned metal cations (Fig. S7, Supplementary data) to evaluate their individual influence toward $\mathrm{Fe}^{3+}$ associated with

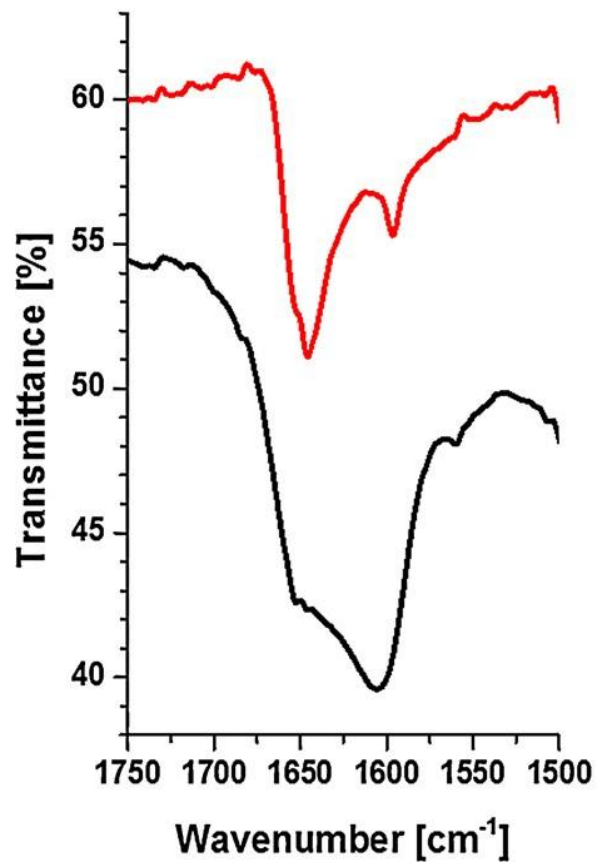

1. It reveals that cations did not individually impact the decrease of fluorescence of 1 toward $\mathrm{Fe}^{3+}$. Furthermore, the presence of all $\mathrm{Li}^{+}, \mathrm{Na}^{+}$, $\mathrm{K}^{+}, \mathrm{Mg}^{2+}, \mathrm{Ca}^{2+}, \mathrm{Al}^{3+}, \mathrm{Cr}^{3+}, \mathrm{Mn}^{2+}, \mathrm{Fe}^{2+}, \mathrm{Ni}^{2+}, \mathrm{Zn}^{2+}, \mathrm{Cd}^{2+}, \mathrm{Hg}^{2+}, \mathrm{Pb}^{2+}$ and $\mathrm{Ga}^{3+}$ did not influence the fluorescence spectrum (Fig. 4) thereby confirming the highly iron (III) selectivity of this new probe. In addition, the $\mathrm{Fe}^{3+} / \mathrm{Fe}^{2+}$ quench ratio of 1:0.1 appears to be interesting for speciation study.

\subsection{Binding pattern and molecular modeling}

Since, it is reasonable to assume that $N$-carbonyl methylene arm of $\mathbf{1}$ is involved in the chelation phenomenon, infrared spectroscopy studies and ${ }^{1} \mathrm{H}$ NMR experiment were carried out to get further information on the nature of complex formation between 1 and $\mathrm{Fe}^{3+}$. The IR spectrum @ 1 was characterized by the ether-crown (C- O-C) stretching band at 1121 $\mathrm{cm}^{-1}$ and the amide carbonyl (C O) regions at $1645 \mathrm{~cm}^{-1}$ respectively (Fig. 5). Upon the addition of $\mathrm{Fe}^{3+}$, both carbonyl and ether absorption bands were shifted to lower frequency $\left(1605\right.$ and $1095 \mathrm{~cm}^{-1}$, respectively) which con- firms that both carbonyl and azacrown ether moiety are involved in the recognition phenomenon [36].

To consolidate the coordination pattern between 1 and $\mathrm{Fe}^{3+}$,

we have performed a ${ }^{1} \mathrm{H}$ NMR experiment in $\mathrm{CD}_{3} \mathrm{CN}$ (Fig. 6). As shown, the addition of 1 equiv. of $\mathrm{Fe}\left(\mathrm{ClO}_{4}\right)_{3}$ induces a shift of methylenic group to $5.31 \mathrm{ppm}$ toward $5.71 \mathrm{ppm}$ that is consistent with IR experiment where the carbonyl moiety was involved in the chelation of $\mathrm{Fe}^{3+}$.

To complete binding pattern of $\mathrm{Fe}^{3+}$ with chemosensor $\mathbf{1}$, molecular modeling was performed using $6.31 \mathrm{G}^{*} / \mathrm{RHF}$ ab initio method based on 1:1 stoechiometry (Fig. 7) previously estimated by BenesiHildebrand plot (Fig. 3, inset) [37]. In our models, we have firstly chelated the iron ion with one molecule of water, oxygen's

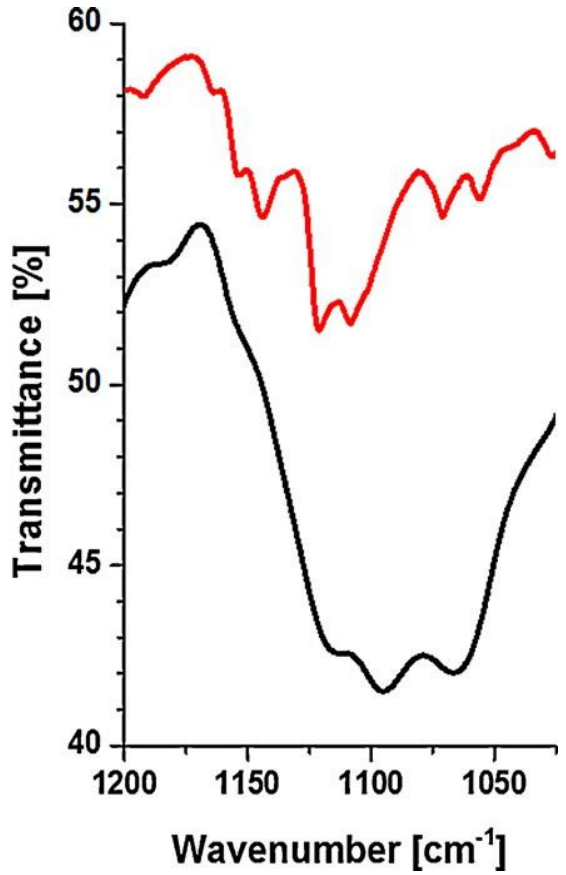

Fig. 5. IR spectra of compound $\mathbf{1}$ (top) and chemosensor $\mathbf{1}$ in the presence of $\mathrm{Fe}^{3+}$ (bottom). 


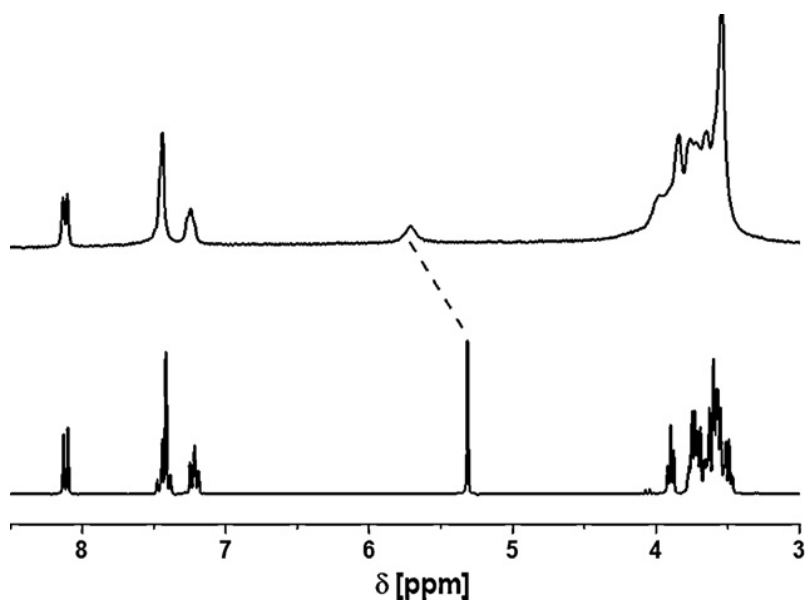

Fig. 6. ${ }^{1} \mathrm{H}$ NMR spectra of $\mathbf{1}$ in $\mathrm{CD}_{3} \mathrm{CN}$ : 1 alone (bottom), $\mathbf{1}+1$ equiv. of $\mathrm{Fe}\left(\mathrm{ClO}_{4}\right)_{3}$ (top)

atoms from crown ether and an additional bond to satisfy the coordination number of $\mathrm{Fe}^{3+}$. This additional bond was, in the one hand, the aromatic part of carbazole unit in order to form cation-G inter- action and, on the other hand, the oxygen of the carbonyl group. The complexation by cation- $\mathbf{G}$ interaction was not energetically favored due to excessive proximity between carbazole moiety and crown ether. Thus, only the optimized structure of Fig. 7B revealed that a metal ion binds with the carbonyl as well as with oxygen atoms from the crown ether moiety.

In consequence, as for alkali metal complex with lariat ether amide described by Gokel and coworkers [38], we assume that the presence of an amide group in probe $\mathbf{1}$ affects the conformation and consequently the binding properties of the macrocyclic azacrown ether which induce the selectivity. Thus, this effective binding affin- ity of iron with the receptor coupled with the absence of quenching effect of other paramagnetic $\mathrm{Cu}^{2+}$ and $\mathrm{Mn}^{2+}$ cations tend to estab- lish that the fluorescent quenching mechanism is due to a static quenching process for the best part but a dynamic quenching pro- cess may also occur at high concentration of iron.

\subsection{Electrochemical properties}

As previously outlined in this paper, electropolymerization by cyclic voltammetry $(\mathrm{CV})$ is an effective technique to create films onto surfaces [39]. Hence, we turned our attention to whether 1 could be electropolymerized onto an electrode surface using this technique. To test the ability to form network ultrathin films,

A

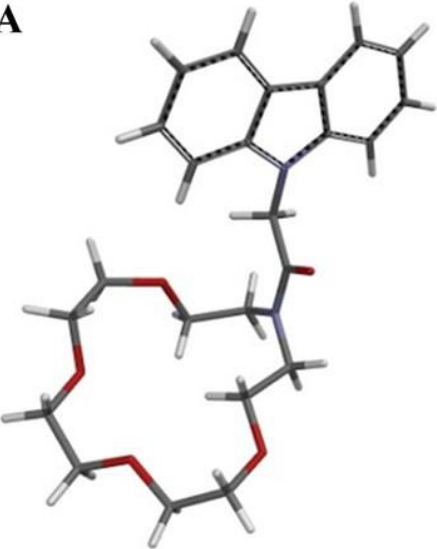

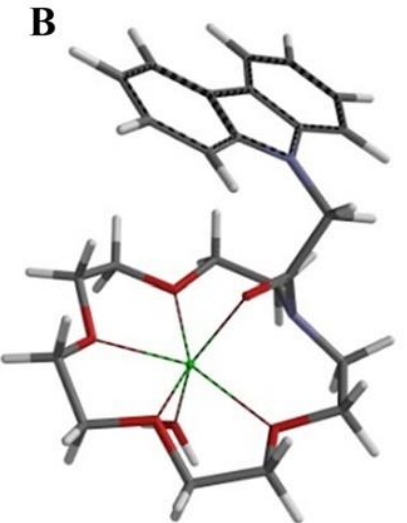

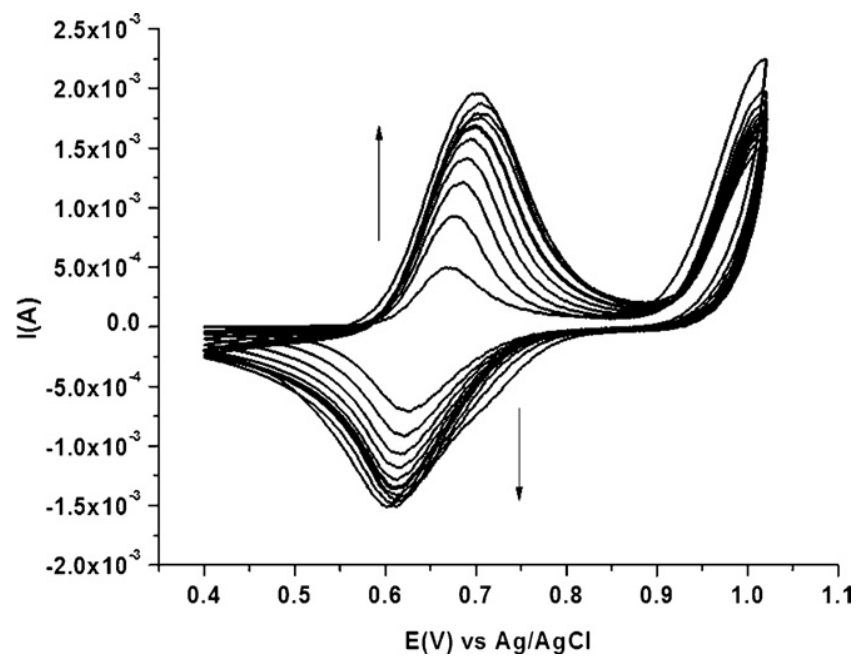

Fig. 8. $\mathrm{CV}$ showing the electrochemical polymerization of 1 from a $10^{-3} \mathrm{M}$ solution in acetonitrile/water $(2: 8)$ with $1 \mathrm{M} \mathrm{HClO}_{4}$. The $\mathrm{CV}$ shows 10 cycles between +0.4 and $+1.0 \mathrm{~V}$. Scan rate $=0.1 \mathrm{~V} \mathrm{~s}^{-1}$.

chemosensor 1 was electropolymerized for 10 cycles (Fig. 8) at a range of $0.4-1.0 \mathrm{~V}$ with a scan rate of $0.1 \mathrm{~V} \mathrm{~s}^{-1}$ in acetonitrile/water mixture (2:8) with $1 \mathrm{M} \mathrm{HClO}_{4}$ as electrolyte (WE, gold-coated slide; CE, Pt wire; $\mathrm{RE}, \mathrm{Ag} / \mathrm{AgCl})$.

The first anodic scan (Fig. S8, Supplementary data) shows an oxidation potential at around $1 \mathrm{~V}$ for $\mathbf{1}$ ascribed to the formation of the carbazole cation radical. During the second scan, a new sharp oxidation wave appears at a lower potential intensities $(0.7 \mathrm{~V})$ indi- cating that the electrochemical-chemical reaction generates an oligomeric/polymeric material that is easier to oxidize than the monomer 1. Upon repeated scans, an increase in the oxidation and reduction currents is observed, indicating the occurrence of the growth of a film onto the working electrode surface according to a radical mechanism [40,41]. Following deposition, the functional- ized surface was successively washed with ultrapure water and its electrochemistry was then investigated in a fresh aqueous solution of $1 \mathrm{M}$ perchloric acid using $\mathrm{CV}$. Oxidative scans between +0.25 and

$+0.90 \mathrm{~V}$ were recorded and clearly revealed the redox wave due to the oxidation of carbazole framework and thus provided clear evi- dence of deposition of carbazole moiety on the electrode surface. Moreover, the current increase of the redox process proved to be linear as a function of the scan rate as expected for surface bound electro-active material (Fig. 9a and $b$ ). The film proved to be reason- ably stable, displaying a similar current/voltage response for more than 10 cycles.

Additionally, the electrodeposition was investigated using a combined electrochemistry and quartz crystal microbalance (EQCM) (Fig. S9, Supplementary data). It is seen that the frequency decreased monotonically with potential scans indicating the pro- gressively deposition of a carbazole film onto the gold surface. The surface coverage $\mathrm{T}$ of the redox species can be calculated by integrating the anodic peak area [42] (charge $Q$ ) according to $\mathrm{T}=Q / n F A$, where $F$ is the Faraday constant, $n$ the number of elec- trons exchanged $(n=0.5$, i.e. only half of carbazole units display a positive charge) [40], and $A$ the surface area $(\varnothing 1.3 \mathrm{~cm})$. The elec-trochemical results show that the surface coverage is $6.9210^{+15}$ molecules per $\mathrm{cm}^{2}$ which is in the same order of magnitude than those previously described for unsubstitued $\mathrm{N}$ carbazole. From our literature knowledge, it is the first time that an $\mathrm{N}$ azacrown car- bazole derivative has been coated as a pendant unit onto a gold working electrode surface via carbazole electro-polymerization. In addition, we attempt to realize similar electrodeposition with the reduced $N$-carbazole-azacrown 4 . No increasing in the oxidation

Fig. 7. Optimized geometry of free 1 (A); $1 . \mathrm{Fe}^{3+}$ (B) by $6.31 \mathrm{G}^{*} / \mathrm{RHF}$ ab initio method. 
A

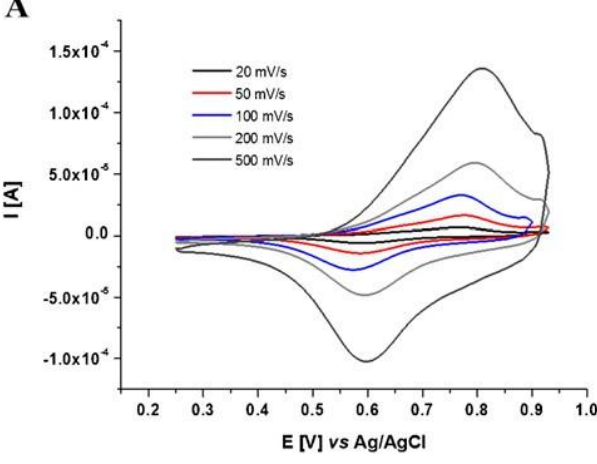

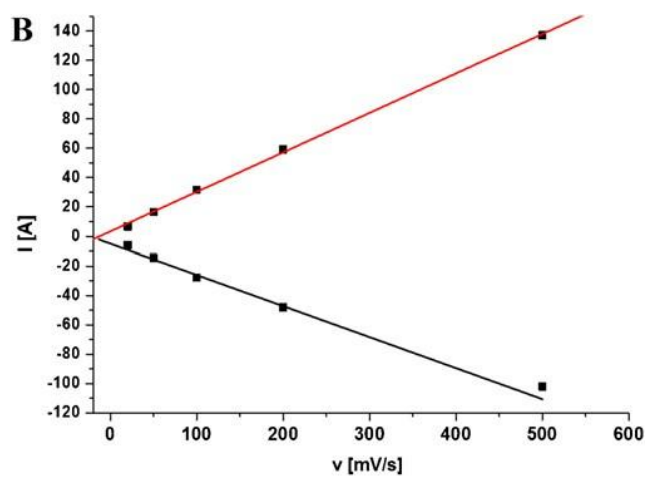

Fig. 9. Cyclic voltamograms at different scan rates of chemosensor 1 - grafted gold surface (left). Peak current as a function of scan rate for anodic and cathodic peaks (right).

and reduction currents could be observed (Fig. S10, Supplementary data). We presume that the protonation of the free tertiary amine is responsible for this lack of electro-deposition because of the high solubility of protonated form of $\mathbf{4}$ in water.

\section{Conclusions}

In conclusion, we have successfully designed a new $N$-azacrown carbazole chemosensor allowing the specific detection of $\mathrm{Fe}^{3+}$ ion. The synthesis was efficiently carried out with good yield and reduced reaction time using microwave-assisted synthesis. We measured a significant and quantifiable decrease of the fluores- cence intensity of chemosensor 1 upon addition of $\mathrm{Fe}^{3+}$. By contrast, the addition of other metals cations such as $\mathrm{Li}^{+}, \mathrm{Na}^{+}, \mathrm{K}^{+}, \mathrm{Mg}^{2+}, \mathrm{Ca}^{2+}, \mathrm{Al}^{3+}, \mathrm{Cr}^{3+}, \mathrm{Mn}^{2+}$, $\mathrm{Fe}^{2+}, \mathrm{Ni}^{2+}, \mathrm{Cu}^{2+}, \mathrm{Zn}^{2+}, \mathrm{Cd}^{2+}, \mathrm{Hg}^{2+}, \mathrm{Pb}^{2+}$ and

$\mathrm{Ga}^{3+}$ do not significantly modify the fluorescence emission allow-

ing the specificity quantification of iron concentration. The non- $\mathrm{pH}$ dependence of the fluorescence properties of 1 provides an effec- tive means for $\mathrm{Fe}^{3+}$ sensing in water. Moreover chemosensor $\mathbf{1}$ was successfully electropolymerized on gold electrode and work is under way in our laboratory to investigate its recognition prop- erties toward metal cations.

\section{Acknowledgements}

We are grateful for the financial support from the Industrial Environmental Institute Research (IRENI) and the French Agency for Food, Environmental and occupational Health \& Safety (2010-368). The authors would like to thank the "Centre Commun de Mesures" of the Universite du Littoral Côte d'Opale for electrospray mass spectroscopy spectra and $\mathrm{Pr}$ David Landy for his precious advices about spectroscopy.

\section{References}

[1] B. Valeur, I. Leray, Design principles of fluorescent molecular sensors for cation recognition, Coordination Chemistry Reviews 205 (2000) 3-40.

[2] J.F. Callan, A.P. de Silva, D.C. Magri, Luminescent sensors and switches in the early 21 st century, Tetrahedron 61 (2005) 8551-8588.

[3] L. Basabe-Desmonts, D.N. Reinhoudt, M. Crego-Calama, Design of fluorescent materials for chemical sensing, Chemical Society Reviews 36 (2007) 993-1017.

[4] J.R. Lakowicz, Principles of Fluorescence Spectroscopy, 2nd ed., Kluwer, New York, NY, 1999

[5] B. Valeur, Molecular Fluorescence: Principles and Applications, Wiley-VCH, Weinheim, Germany, 2002.
[6] I. Móczár, P. Huszthy, A. Mezei, M. Kádár, J. Nyitrai, K. Tóth, Synthesis and optical characterization of novel azacrown ethers containing an acridinone or an $\mathrm{N}$ methylacridinone unit as potential fluorescent chemosensors, Tetrahedron 66 (2010) $350-358$.

[7] L. Wang, W. Qin, W. Liu, A sensitive Schiff-base fluorescent indicator for the detection of $\mathrm{Zn}^{2+}$, Inorganic Chemistry Communications 13 (2010) 1122-1125.

[8] P. Dinake, P.E. Prokhorova, V.S. Talanov, R.J. Butcher, G.G. Talanova, A new fluorogenic calix[4]arene $\mathrm{N}$-dansylcarboxamide in the cone conformation for selective optical recognition of mercury(II), Tetrahedron Letters 51 (2010) 50165019.

[9] X.B. Zhang, G. Cheng, W.J. Zhang, G.L. Shen, R.Q. Yu, A fluorescent chemical sensor for $\mathrm{Fe}^{3+}$ based on blocking of intramolecular proton transfer of a quinazolinone derivative, Talanta 71 (2007) 171-177.

[10] M. Kumar, R. Kumar, V. Bhalla, On-Off reversible switch for $\mathrm{Fe}^{3+}$ and $\mathrm{F}^{-}$ mimicking XNOR logic function, Tetrahedron Letters 51 (2010) 5559-5562.

[11] R. Peng, F. Wang, Y. Sha, Synthesis of 5-dialkyl(aryl)aminomethyl-8 hydroxyquinoline dansylates as selective fluorescent sensors for $\mathrm{Fe}^{3+}$, Molecules 12 (2007) 1191-1201.

[12] D. Kennedy, D. Brown, S. Burdette, Probing nitrobenzhydrol uncaging mecha- nisms using ferricast, Organic Letters 12 (2010) 4486-4489.

[13] Y. Xiang, A. Tong, New rhodamine-based chemosensor exhibiting selective $\mathrm{Fe}^{3+}$ amplified fluorescence, Organic Letters 8 (2006) 1549-1552.

[14] Z. Hu, Y. Feng, H. Huang, L. Ding, X. Wang, C. Lin, M. Li, C. Ma, Fe ${ }^{3+}$ selective fluorescent probe based on rhodamine B and its application in bioimaging, Sensors and Actuators B: Chemical 156 (2011) 428-432.

[15] W. Yin, H. Cui, Z. Yang, C. Li, M. She, B. Yin, J. Li, G. Zhao, Z. Shi, Facile synthesis and characterization of rhodamine-based colorimetric and off-on flu- orescent chemosensor for $\mathrm{Fe}^{3+}$, Sensors and Actuators B: Chemical 157 (2011) 675-680.

[16] S. Dalapati, S. Jana, Md.A. Alam, N. Guchhait, Multifunctional fluorescent probe selective for $\mathrm{Cu}(\mathrm{II})$ and $\mathrm{Fe}(\mathrm{III})$ with dual-mode of binding approach, Sensors and Actuators B: Chemical 160 (2011) 1106-1111.

[17] N. Narayanaswamy, T. Govindaraju, Aldazine-based colorimetric sensors for $\mathrm{Cu}^{2+}$ and $\mathrm{Fe}^{3+}$, Sensors and Actuators B: Chemical 161 (2012) 304-310.

[18] B.P. Esposito, S. Epsztejn, W. Breuer, Z.I. Cabantchik, A review of fluorescence methods for assessing labile iron in cells and biological fluids, Analytical Biochemistry 304 (2002) 1-18

[19] J. Hua, Y.G. Wang, A highly selective and sensitive fluorescent chemosensor for $\mathrm{Fe}^{3+}$ in physiological aqueous solution, Chemistry Letters 34 (2005) 98-99.

[20] J. Yao, W. Dou, W. Qin, W. Liu, A new coumarin-based chemosensor for $\mathrm{Fe}^{3+}$ in water, Inorganic Chemistry Communications 12 (2009) 116-118.

[21] N. Singh, N. Kaur, J. Dunn, M. MacKay, J.F. Callan, A new fluorescent chemosen- sor for iron(III) based on the p-aminobisulfonate receptor, Tetrahedron Letters 50 (2009) 953-956.

[22] K.S. Moon, Y.K. Yang, S. Ji, J. Tae, Aminoxy-linked rhodamine hydroxamate as fluorescent chemosensor for $\mathrm{Fe}^{3+}$ in aqueous media, Tetrahedron Letters 51 (2010) 3290-3293.

[23] E. Sezer, J. Heinze, Voltammetric, EQCM and in situ conductivity stud- ies of 3,6-bis(2-thienyl)-N-ethyl carbazole, Electrochimica Acta 51 (2006) 3668-3673.

[24] V. Saxena, V. Shirodkar, R. Prakash, Copper(II) ion-selective microelectrochem- ical transistor, Journal of Solid State Electrochemistry 4 (2000) 234-236.

[25] F. Delattre, P. Woisel, G. Surpateanu, F. Cazier, P. Blach, 1-(4Nitrophenoxycarbonyl)-7-pyridin-4-yl indolizine: a new versatile fluorescent building block. Application to the synthesis of a series of fluorescent betacyclodextrins, Tetrahedron 61 (2005) 3939-3945.

[26] I. Mallard Favier, P. Blach, F. Cazier, F. Delattre, Efficient synthesis of a fluorescent tripod detection system for pesticides by microwave-assisted click chemistry, Carbohydrate Research 344 (2009) 161-166.

[27] A.V. Tsukanov, A.D. Dubonosov, V.A. Bren, V.I. Minkin, Organic chemosensors with crown-ether groups, Chemistry of Heterocyclic Compounds 44 (2008) 899-922. 
[28] H. Maeda, S. Furuyoshi, Y. Nakatsuji, M. Okahara, Synthesis of monoaza crown ethers from N,N-di[oligo(oxyalkylene)]amines and oligoethylene glycol di(ptoluenesulfonates) or corresponding dichloride's, Bulletin of the Chemical Society of Japan 56 (1983) 212-218.

[29] P.-E. Danjou, D. Wallyn, F. Cazier-Dennin, F. Delattre, Ultrasound-promoted tosylation of oligo(ethylene glycols), Ultrasonics Sonochemistry 19 (2012) 12011204.

[30] X.J. Zhang, Y.P. Tian, S.L. Li, M.H. Jiang, A. Usman, S. Chantrapromma, H.K. Fun, $\mathrm{Zn}(\mathrm{II})$ and $\mathrm{Cd}(\mathrm{II}) \mathrm{N}$-carbazolylacetates with strong fluorescence, Polyhedron 22 (2003) 397-402.

[31] E.S. Meadows, L.J. Barbour, R. Ferdani, G.W. Gokel, Dimer formation in alkali metal complexes of $15-$ and 18 -membered indole-containing lariat ether amides, Journal of Supramolecular Chemistry 1 (2001) 111-115.

[32] G. Cooke, V.M. Rotello, A. Radhi, Fluorocarbonyltetrathiafulvalene: an effec- tive building block for the production of tetrathiafulvalene esters and amides, Tetrahedron Letters 40 (1999) 8611-8613.

[33] CAUTION: Perchlorates salts are explosives materials it should be handle with care.

[34] Y. Wang, T. Ikeda, H. Ikeda, A. Ueno, F. Toda, Dansyl-p-cyclodextrins as fluores- cent sensors responsive to organic compounds, Bulletin of the Chemical Society of Japan 67 (1994) 1598-1607.

[35] L. Zhang, B. Li, Z. Su, S. Yue, Novel rare-earth(III)-based water soluble emitters for Fe(III) detection, Sensors and Actuators B: Chemical 143 (2010) 595-599.

[36] X. Zhang, Y. Shiraishi, T. Hirai, Fe(III)- and $\mathrm{Hg}$ (II)-selective dual channel fluorescence of a rhodamine-azacrown ether conjugate, Tetrahedron Letters 49 (2008) $4178-4181$.

[37] J.H. Hildebrand, H.A. Benesi, A spectroscopic investigation of the interaction of iodine with aromatic hydrocarbons, Journal of the American Chemical Society 71 (1949) 2703-2707.

[38] J. Hu, L.J. Barbour, R. Ferdani, G.W. Gokel, Solid state network formation in arene-sidearmed lariat ether complexes: Contrasting behavior of sodium, potassium, and calcium cation complexes, Journal of Supramolecular Chem- istry 1 (2001) 157 163.

[39] G. Cooke, L.M. Daniels, F. Cazier, J.F. Garety, S.G. Hewage, A. Parkin, G. Rabani, V.M. Rotello, C.C. Wilson, P. Woisel, The synthesis of a pyrrole-functionalized cyclobis(paraquat-p-phenylene) derivative and its corresponding [2] rotaxane and [2]catenane and their subsequent deposition onto an electrode surface, Tetrahedron 63 (2007) $11114-11121$.

[40] I. György, Formation and redox behaviour of polycarbazole prepared by electropolymerization of solid carbazole crystals immobilized on an electrode surface, Journal of Solid State Electrochemistry 7 (2003) 503-510.

[41] G. Jiang, R. Ponnapati, R. Pernites, C.D. Grande, M.J. Felipe, E. Foster, R. Advin- cula, Nanoparticle formation and ultrathin film electrodeposition of carbazole dendronized polynorbornenes prepared by ring-opening metathesis polymer- ization, Langmuir 26 (2010) 17629-17639.

[42] M.A. Watson, J. Lyskawa, C. Zobrist, D. Fournier, M. Jimenez, M. Traisnel, L. Gengembre, P. Woisel, A. Clickable, Titanium surface platform, Langmuir 26 (2010) $15920-15924$.

\section{Biographies}

Pierre-Edouard Danjou obtained his M.Sc. degree in organic and macromolecu- lar chemistry from the University of Sciences and Technologies of Lille 1, France in 2009 Currently, he is pursuing a Ph.D. degree in organic chemistry at the Univer- sity of Littoral Côte d'Opale of Dunkerque, France. His research work is focused on the development of novel fluorescent crown-ether-based chemosensor for metal cations.

Joël Lyskawa received his Ph.D. in organic chemistry from the University of Angers in 2004 for his work on TTF-Based Redox-Switchable Ligand. He spent one year in 2005 in the Department of Chemistry of Université du Québec à Montréal as a postdoctoral research associate. He joined the University of Lille 1 in 2006. His current research interests are focused on the elaboration of smarts supramolecular polymers as well as the chemical functionalization of surfaces for biomedical applications.

Franc, ois Delattre received his Ph.D. in organic chemistry from the University of Lit- toral Côte d'Opale of Dunkerque in 2003 for his work on fluorescent p-cyclodextrins. He is actually an assistant professor at the University of Littoral Côte d'Opale. His current researches are focused on the studies of fluorescent probe and switch as well as on the elaboration of hybrids materials for environmental analysis.

Matthieu Becuwe received his Ph.D. in chemistry from the University of Littoral Côte d'Opale of Dunkerque in 2009 for his work on hybrids materials for the detection of VOC. After a postdoctoral position in Dr Clément Sanchez's group, he has recently joined the University of Picardie as assistant professor and work actually on the development of original hybrids materials for energy storage and conversion.

Patrice Woisel is a professor in polymer science at the University of Sciences and Technologies of Lille 1. His research interest includes the synthesis and control of smart supramolecular polymers, the elaboration of stimulable surfaces and the functionnalization of titanium based biomaterials.

Steven Ruellan received his M.Sc. Degree in molecular chemistry from University of Rennes I, France, in 2004, working on the development of new monofluorinated analogs for medicinal chemistry. He is currently working as an engineer at the Uni- versity of Littoral Côte d'Opale of Dunkerque. His research interests include the development of organic materials for trapping and detection of pollutants.

Sophie Fourmentin received her Ph.D. in organic and macromolecular chemistry from the University of Science and Technologies of Lille 1, France in 1994. She is actu- ally professor in supramolecular chemistry at the University of Littoral Côte d'Opale, in Dunkerque. Her research interest is focused on the development of remediation processes based on supramolecular chemistry and on the analytical characterization of host-guest complexes.

Francine Cazier-Dennin received her Ph.D. in organic and macromolecular chem- istry from the University of Sciences and Technologies of Lille 1, France in 1989. She is actually assistant professor at the University of Littoral Cote d'Opale. Her research interests include sonochemistry and microwave-assisted organic synthesis of novel fluorescent chemosensors based on supramolecular entities. 